\title{
Podpora studentů se SP na PedF UK
}

\section{Support for students with special needs at the Faculty of Education, Charles University}

\author{
Anna Kucharská ${ }^{1}$, PedF UK, Praha \\ Kristýna Janyškováa , PedF UK, Praha
}

\begin{abstract}
Abstrakt
Univerzita Karlova již dlouhodobě podporuje vstup studentů se specifickúmi potřebami na její fakulty. Uchazečům i studentům se specifickými potřebami poskytuje podporu nebo úpravy studia a prostředí, jejichž cílem je vytuořit podmínky pro maximální využití jejich potenciálu v akademickém životě. Př́spěvek představuje systém podpory studentů se specifickými potřebami na Pedagogické fakultě, do něhož se zapojují odborní pracouníci Akademické poradny, dále kontaktní osoba fakulty, kontaktní osoby kateder a v neposlední řadě také samotní vyučující. Příspěvek shrnuje nabízené služby a úpravy, které mohou čerpat jak studenti, tak i pedagogové, kteří vyučují studenta se specifickými potřebami. Informuje i o výsledcích evaluačního šetření, které bylo provedeno mezi studenty se specifickými potřebami a kontaktními pracovníky na katedrách.
\end{abstract}

\section{Klíčová slova}

studenti se specifickými potřebami, vysoká škola, podpora

\begin{abstract}
Charles University has a long tradition in supporting the students with special needs. In this spirit, Charles University provides applicants and students with special needs with support or adjustments of their studies and environment with the aim to create conditions for the maximum use of their potential in academic life. The paper presents a sophisticated system of support for students with special needs at the Faculty of Education, which involves experts from the Academic Counselling Centre, which was specially established for this purpose, the contact person of the faculty, contact persons of the departments and last, but not least the teachers. The paper also summarizes the services, education, aids and adjustments that can be used free of charge by both students and teachers who teach students with special needs.
\end{abstract}

\section{Keywords}

students with special needs, university, support

\section{1 Úvod}

Pedagogická fakulta Univerzity Karlovy se dlouhodobě zabývá podporou a uplatňováním servisních opatření ve prospěch studentů se specifickými potřebami (dále jen studentů se SP). Každoročně také provádí evaluační šetření mezi studenty se $\mathbf{S P}^{3}$, která pomáhají postihnout aktuální stav podpory studentů se SP i případné obtíže s poskytováním podpůrných prvků pro studium na vysoké škole. Evaluační šetření, uskutečněné začátkem roku 2021, si kromě jiného kladlo za cíl zjistit, jak studenti se SP, ale také 
tzv. kontaktní osoby na katedrách, vnímají činnost Akademické poradny Pedagogické fakulty, která funguje v nových podmínkách od roku 2019 prostřednictvím projektu ESF.

\section{Studenti se specifickými potřebami na vysokých školách}

Právo na vzdělání mají podle platných legislativních dokumentů všechny osoby, včetně osob se zdravotním postižením či znevýhodněním. Vysoké školy mají povinnost uzpůsobovat podmínky pro přijímací řízení i pro studium u studentů se SP. Ministerstvo školství podporuje specifické přístupy a servisní opatření prostřednictvím navýšeného příspěvku na studenta se SP (Pravidla pro poskytování příspěvku a dotací veřejným vysokým školám MŠMT, př́loha 3)5.

Za studenta se SP je pokládán student, který vzhledem k vrozené nebo získané povaze svého zdravotního stavu vyžaduje modifikaci studijních podmínek a kontrol studia, odstranění fyzických překážek, případně jiné úpravy prostor za účelem úspěšného průběhu studia. Mezi studenty a uchazeče se SP řadíme studenty se zrakovým postižením (kategorie A), se sluchovým postižením (kategorie B), s tělesným a pohybovým postižením (kategorie $\mathrm{C}$ ), se specifickými poruchami učení (kategorie D), s poruchou autistického spektra (kategorie E), s kombinovaným postižením a studenty s jinými obtížemi (s duševními poruchami, s narušenými komunikačními schopnostmi, s chronickými a somatickými onemocněními, kategorie F) (MŠMT, příloha 3, opatření rektora č. 23/2017).

\subsection{Studenti se specifickými potřebami na Univerzitě Karlově}

Na Univerzitě Karlově existuje delší dobu pracovní skupina odborníků, kteří se podílejí na nastavování pravidel pro poskytování služeb ve prospěch studentů se SP i na jejich hodnocení. Z titulu tohoto orgánu byla formulována základní pravidla podpory studentů se SP, která se následně promítla i do Opatření rektora 23/2017, což je legislativní opora pro tuto činnost.

Podíváme-li se v grafu 1 na počty evidovaných studentů se SP, je zřejmé, že se v průběhu času zvyšuje počet studentů, kteří nacházejí podporu při studiu. Zatímco v roce 2012 činil poměr evidovaných studentů pouze 0,28 \% z celkového počtu studentů, v roce 2020 je to již 1,43 \% studentů. Univerzita Karlova patřík vysokým školám, které se pohybují nad celostátním průměrem v počtu studentů se SP, kdy v roce

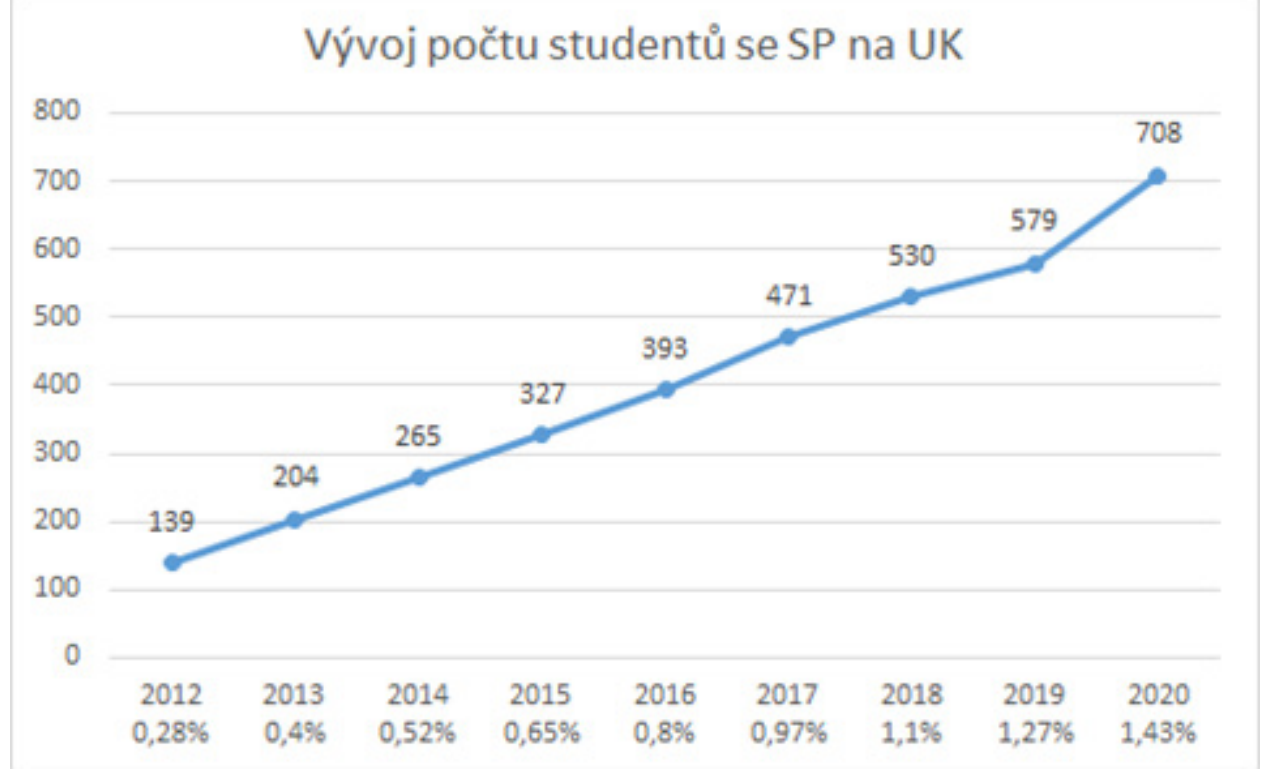

2020 byl průměr studentů se SP ve výši 1,1% celkové vysokoškolské populace v ČR (Peňáz, 2021).

Graf 1. Vývoj počtu studentů se SP na UK (v letech a percentuálních podílech).

Zdroj: Centrum Carolina, UK.

Ústředním orgánem podpory studentů se SP je na UK Centrum Carolina. Kromě toho, že koordinuje celý systém služeb, některé z nich i přímo poskytuje. Přitom jsou rozlišovány tzv. centralizované služby, což jsou služby, které poskytují pracoviště rektorátu nebo jiná univerzitní pracoviště pro všechny studenty 4 ESF pro VŠ II na UK, CZ.02.2.69/0.0/0.0/18_056/0013322

5 Dostupné z: https://www.msmt.cz/vzdelavani/vysoke-skolstvi/pravidla-pro-poskytovani-prispevku-a-dotaci-verejnym-vysokym-2) 
se SP, bez příslušnosti k fakultě, kde studují a decentralizované služby. To jsou služby jednotlivých fakult pro své studenty.

K centralizovaným službám patří např. funkční diagnostika (postup nutný pro evidenci studentů se SP) a další služby: digitalizace textů, studijní asistence a nácvik studijních strategií, tlumočnické, přepisovatelské a zapisovatelské služby. Fakulty se v největší míře starají o podporu uchazečůstsudentů se SP v přijímacím ř́́zení i při studiu (decentralizované služby).

Univerzita má vyčleněné pracovníky, kteří poskytují metodickou podporu studentům se SP dle příslušných kategorií, tito pracovníci komunikují jak s dotčenými studenty, tak s pověřeným pracovníkem fakulty. Centrum Carolina podporuje také poradenské služby a je v kontaktu s jednotlivými vysokoškolskými poradnami, které jsou zřízeny na pěti fakultách univerzity. Akademická poradna PedF, kterou v tomto př́spěvku představujeme, je jednou z nich.

Aby mohl student se SP využívat systému podpory, musí být oficiálně registrován prostřednictvím SIMS (Sdružené informace matrik studentů, MŠMT). Kromě dokladu, který musí student předložit, a podpisu informovaného souhlasu, musí být provedena funkční diagnostika. Je to diagnostický rozhovor - zhruba hodinový - se studentem. V rámci něj jsou zjištóovány studentovy zkušenosti se vzděláváním, s modifikacemi a úpravami na nižších stupních studia (nebo na jiné vysoké škole, v jiném studijním programu), identifikovány oblasti, v nichž bude třeba vhodně nastavit modifikace. Pověřený pracovník poradny předpovídá a odhaluje možné obtíže vyplývající ze studentova zdravotního stavu. Posudek funkční diagnostiky se stává po jeho podpisu a udělení studentova souhlasu s jeho evidencí prostředkem zařazení mezi studenty se SP.

\subsection{Studenti se specifickými potřebami na Pedagogické fakultě UK}

Pedagogická fakulta má tradici v podpoře ohrožených skupin studentů. Již koncem 80. let byla formována Akademická poradna při katedře pedagogické a školní psychologie, v 90. letech vznikla poradna pro studenty s handicapy při katedře speciální pedagogiky.

Z výročních zpráv Pedagogické fakulty jsou převzaty údaje o počtu evidovaných studentů se SP od roku 2008, kdy poměr činil pouze 0,48 \% studentů se SP z celkového počtu studentů. Z grafu 2 je zřejmé, že se počty stále zvyšují. V roce 2020 to již bylo 1,81 \% z celkového počtu studentů. Pedagogická fakulta je na univerzitě mezi fakultami s největším počtem studentů se SP. Relativně i absolutně převyšuje i celostátní průměr (jak bylo uvedeno výše, průměr v ČR je 1,1% studentů se SP v roce 2020).

Zvyšování počtu studentů v jednotlivých kategoriích specifických potřeb dle metodiky MŠMT není srovnatelné (graf 3). Zatímco počty studentů se smyslovým a pohybovým postižením (kategorie A, B, C) se dlouhodobě pohybují v podobné míre, nejvíce se zvyšují počty studentů se specifickými poruchami učení (kategorie D) a dalšími obtížemi (kategorie F). Je to pochopitelné, nebot' všeobecně v populaci je více jedinců s poruchami učení (dle údajů z MŠMT 8-9 \%) a psychickými problémy nebo zdravotním omezením, než jedinců se smyslovým a pohybovým postižením. Kategorie E, tedy studenti s poruchami autistického spektra, která byla vyčleněna až v roce 2016 z kategorie jiných obtíží, doznává zvyšování počtu též.

Přes tato zvyšující se čísla je potřeba také ale zmínit to, že studentů se SP by mělo být mnohem více, vycházíme-li z pravděpodobného počtu studentů daných obtíží v běžné populaci. Tito studenti jistě na fa-

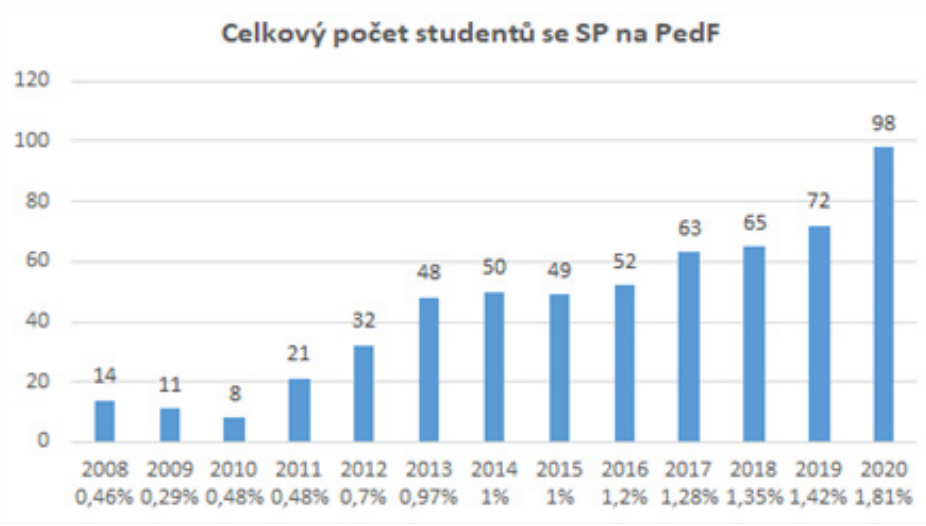

kultě jsou, jen studují zatím „V utajení“ (Kucharská, Špačková, \& Sotáková, H., 2021).

Graf 2. Přehled absolutních i relativních počtů studentů se SP na PedF UK. 


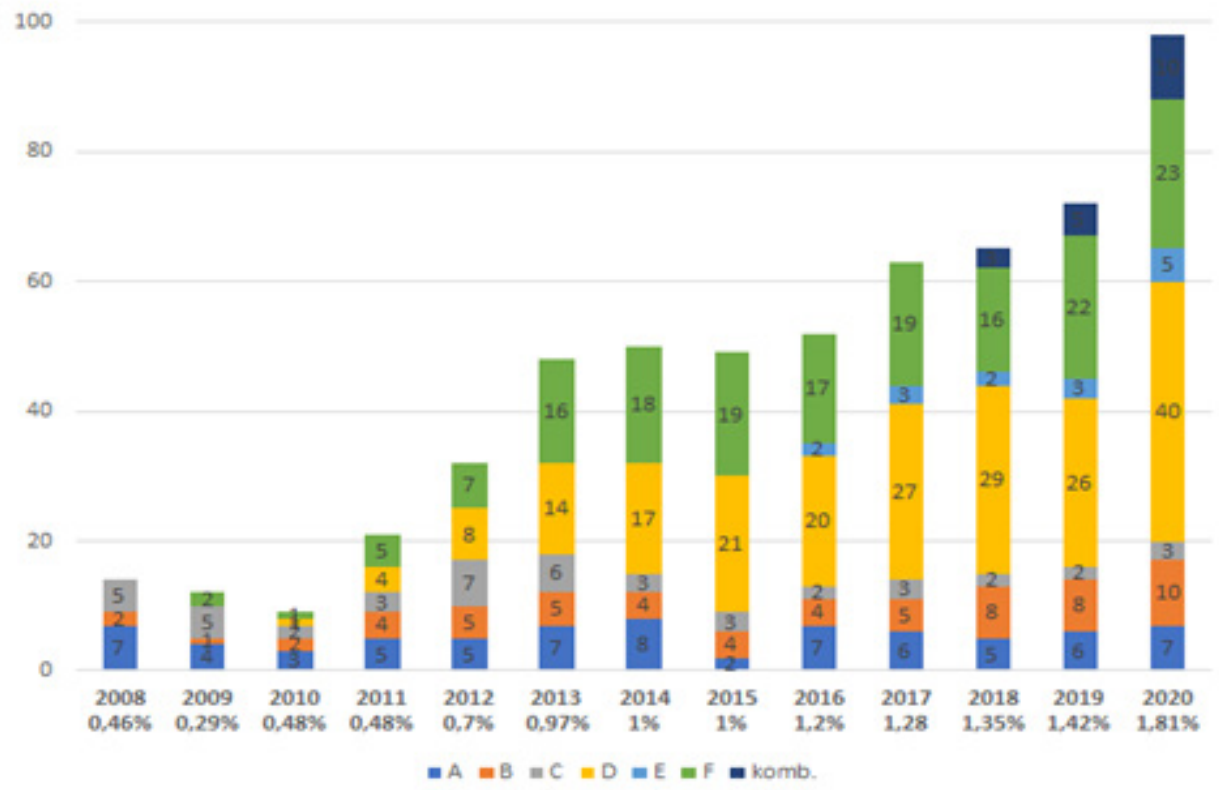

Zdroj: Výroční zprávy PedF UK.

\section{Graf 3. Vývoj počtu studentů se speciálními potřebami v jednotlivých kategoriích. Zdroj: Výroční zprávy PedF UK.}

Hlavní koordinátorkou systému podpory studentů se SP je tzv. kontaktní osoba fakulty, kterou jmenuje děkan po projednání s prorektorkou pro studium. Pomáhá chránit a uplatňovat oprávněné zájmy studentů se SP, pomáhá řešit obtí̌ze vzniklé během studia a v př́ípadech závažných problémů je to právě ona, kdo problém řeší. Řídí také činnosti referentky pro studenty se SP. Ta řeší se studenty obtíže vyplývající z jejich zdravotního stavu, obtíže při studiu a zavádění modifikací při atestacích a při studiu. V př́padě potřeby facilituje komunikaci studenta se SP s dalšími osobami na fakultě (s vyučujícími, s kontaktními osobami/vedoucími kateder, s kontaktní osobou fakulty a zejména zpočátku s odborníkem, který studentovi vystaví posudek funkční diagnostiky). Ve spolupráci se studentem navrhuje vhodné služby (např. efektivní učení) a opatření, jichž může student využívat. Dále studentům pomáhá v orientaci ve Studijním informačním systému (SIS), při orientaci v budovách fakulty a jakýchkoli jiných obtížích studijního i osobního charakteru.

Každý student spadá v oblasti řešení studijních povinností ještě pod jednu studijní referentku, která spravuje studentovu běžnou studijní agendu (např. zápisy do studia, postup do vyššího úseku studia, veškeré žádosti atp.). Ta úzce spolupracuje s referentkou pro studenty se SP, která spravuje studentovu agendu speciálních potřeb. Formální dokumenty jsou odděleny, referentka pro studenty se SP má vlastní evidenci, která je realizována dle zásad GDPR a Zákona o ochraně osobních dat.

Od roku 2019 funguje prostřednictvím projektu ESF sdružená Akademická poradna PedF UK, jejǐž činnost vychází z dřívějších zkušeností poraden na katedře psychologie a speciální pedagogiky, jak bylo uvedeno výše. Novinkou však je, že jsou poradci smluvně vázáni právě na poskytování poradenských služeb - a to nejenom studentům se SP, ale i všem dalšími potřebným studentům i ohroženým skupinám studentů (napřs. studentům se sníženým socio-ekonomickým statusem, v tíživé životní situaci, studentům-rodičům a dalším).

Pracovníci poskytují psychologické a speciálně pedagogické poradenství, novou aktivitou je logopedie. Služby jsou určeny pro všechny studenty i pracovníky univerzity. Studentům jsou dále určeny volitelné předměty (např. studijní strategie, jóga pro studenty se zdravotním znevýhodněním), prostřednictvím kterých může docházet k dalšímu rozvoji osobnosti studenta i jeho kompenzačních a rehabilitačních možností. Vyvíjeny jsou i aktivity pro vyučující z celé univerzity (vzdělávací programy, mediace mezi studentem a vyučujícím, osobní problémy vyučujících, metodické vedení a supervize). 
Pro oblast specifických potřeb v kategoriích A-F vyčlenila fakulta odborníky (tzv. diagnostiky) z řad zástupců katedry psychologie a speciální pedagogiky, kteří mají v daných kategoriích mnohaleté odborné znalosti. Tito odborníci po vzájemné dohodě vyhotoví studentovi posudek funkční diagnostiky, který ho následně opravňuje k využívání přiznaných modifikací.

Kontaktní pracovník pro studenty se SP je vyčleněn také v knihovně. Jeho agendou je poskytování rad, podpory, vyhledávání publikací, kopírování, zajištování literatury v elektronické verzi či ve verzi pro studenty se SP, zejména se zrakovým postižením.

Oddělení pro zahraniční vztahy poskytuje studentům služby týkající se zahraničních aktivit, do nichž je PedF UK zapojena. Organizuje jejich vyslání k různým studijním pobytům v zahraničí, přijímá studenty ze zahraničních vysokých škol, zabezpečuje pobyt zahraničních studentů se SP studujících na PedF.

Oddělení pro vědeckou činnost, kam spadají studenti doktorského studia, úzce spolupracuje s referentkou pro studenty se SP a odborníky Akademické poradny, nebot' také studenti-doktorandi čerpají podpůrných služeb při svém studiu na PedF.

Na každé katedře je jako kontaktní pracovník pro studenty se SP vyčleněna jeden osoba, která je proškolena pro práci se studenty se SP a zároveň velmi dobře zná poměry na dané katedře. Mưže tak studentům pomoci identifikovat možné rizikové oblasti ve studiu. Při zavádění modifikací je pro některé studenty vyčerpávající kontaktovat každého jednotlivého vyučujícího a probírat s ním své nároky na modifikaci výuky. V takovém případě mohou o pomoc požádat právě kontaktní osobu katedry, která jim pomůže navázat se všemi vyučujícími katedry kontakt nebo přímo za studenta tuto úlohu převezme a vybraným vyučujícím poskytne o studentových modifikacích informace (samozřejmě s předchozím souhlasem studenta).

Další tradicí, na kterou je možné upozornit, je poskytování kolegiální podpory mezi studenty. V roce 2011 a 2012 byl realizován celouniverzitní projekt Studenti radí studentům, prostřednictvím kterého se nastavil systém tzv. tutorských služeb. Jednalo se o kolegiální podporu, kdy se studenti vyšších ročníků, pod vedením studijních proděkanek, scházeli se studenty nižších ročníků a řešili s nimi vzniklé potíže. Velmi důležitou úlohu měli při zahájení studia, kdy nově nastupujícím studentům pomáhali s orientací ve vysokoškolském studiu. Aktivita přinesla také každoroční vydávání příručky PedInfo pro studenty prvních ročníků. Obě aktivity se osvědčily a jsou realizovány dodnes, již jako součást podpůrných služeb fakulty.

Ukázalo se, že je potřeba ze studentských tutorů vyčlenit skupinu, která bude k dispozici studentům se specifickými potřebami, ta je tvořena studenty psychologie a speciální pedagogiky, kteří poskytují podporu různého rázu (nap̌r. zápis do předmětů, kontrolu studijního plánu, seznámení s chodem fakulty), přičemž těžiště této podpory tkví v jejím neformálním charakteru.

\section{Metoda}

Pedagogická fakulta přistupuje k podpoře studentů se SP velmi zodpovědně a neustále usiluje o zlepšování poskytovaných služeb. Za tímto účelem realizuje již pravidelně každoroční hodnocení služeb, které vyplňují jak pracovníci fakulty, tak zejména samotní studenti se SP. Hodnocení v roce 2021 mělo širší charakter, zaměřovali jsme se jednak na mapování distanční výuky u studentů se SP (Kucharská, Janyšková, v recenzním ř́zení) a na informovanost a percepci zajištění problematiky podpory studentů se SP na fakultě a na poskytování poradenských služeb skrze nově organizovanou Akademickou poradnu PedF UK. Druhá část našeho šetření (označeno tučně) je představena v našem příspěvku.

Dotazníkového šetření, které bylo distribuováno prostřednictvím Google Forms na začátku kalendářního roku, se zúčastnilo:

- 29 studentů se SP (21 žen a 7 mužơ 1 respondent se odpovědi v otázce pohlaví zdržel), osloveni byli všichni registrovaní studenti se specifickými potřebami. Průzkum byl realizován anonymně v souladu s GDPR a Zákonem o ochraně osobních údajů. Přehled studentů dle specifických potřeb je uveden v tabulce 1.

• 24 pracovníků PedF - 21 kontaktních osob kateder, kontaktní osoba fakulty a 2 referentky pracující se studenty se speciálními potřebami.

V našem příspěvku představíme výsledky, týkajících se odpovědí studentů i vyučujících. 


\begin{tabular}{|c|c|c|c|c|c|c|}
\hline \multicolumn{7}{|c|}{ Tabulke 1. PFehled studentì se S? } \\
\hline Kategorie dle metodiky MS'MT & A & $\mathrm{B}$ & C & D & $\mathrm{E}$ & $\mathrm{F}$ \\
\hline \multirow{2}{*}{ PoCet respondentū celkem (mužú / 2̌en) } & 1 & 5 & 2 & 10 & \multirow{2}{*}{0} & 11 \\
\hline & $(1 / 0)$ & $(1 / 3)$ & $(1 / 1)$ & $(1 / 9)$ & & $(3 / 8)$ \\
\hline Evidovan[ studenti celkem & 7 & 12 & 8 & 38 & 4 & 27 \\
\hline
\end{tabular}

\section{Výsledky šetření}

\subsection{Povědomí studentů o systému podpory na UK/PedF a využíaání tohoto systému}

Každoročně oslovujeme studenty se SP při vstupu na fakultu, jednak písemnou komunikací, jednak na tzv. předstudijním soustředěním. Poskytujeme jim základní informace, koho mohou kontaktovat, budou-li potřebovat nějakou pomoc ve studijních záležitostech. Proto nás zajímalo, jak se ve službách orientují a zda vědí, na koho se mohou obracet. Transparentnost a přehlednost našich služeb je velmi důležitá a snažíme se, aby měli studenti co nejsnazšś a nejintuitivnější přístup k informacím a službám, které aktuálně potřebují.

Jak je zřejmé z grafu 4, skoro dvě pětiny se v systému orientují a služby využívají. Více než polovina respondentů sice systém podpory zná, ale zatím nepotřebuje žádné služby, což je poměrně překvapující. Je ale možné, že do této odpovědi studenti se SP nezahrnuli čerpání podpůrných opatření přímo ve výuce, ale vyslovovali se spíše k personální podpoře mimo katedru. Malá část studentů přiznala, že se neorientu-

Vite, na koho se obrátit v prípadẻ, že budete při studiu potřebovat poradit nebo pomoci?

29 odpovédi
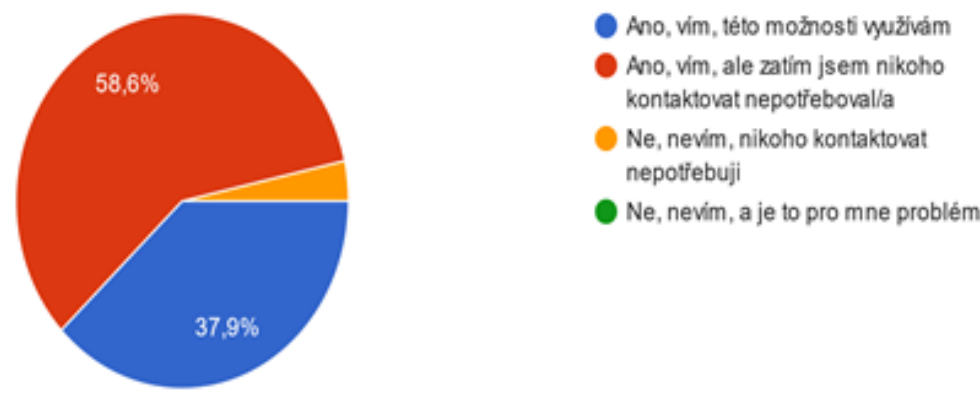

je, ale také nikoho zatím kontaktovat nepotřebovala.

\section{Graf 4. Orientace v nabízených službách.}

Dále nás zajímalo povědomí o Akademické poradně. Sdružení spíše dvou neformálních poradenských služeb do jedné oficiálně vedené poradny bylo jedním z východisek zkvalitnění služeb.

Odpovědi nám říkají (viz graf 5), že studenti poradnu znají (téměř polovina), přitom další třetina o poradně ví, avšak zatím si nezjištovala nabídku jejích služeb. Pětina přiznává malou či žádnou obezná-

\section{Vite, že má naše fakulta Akademickou poradnu? Vite, kde ji najdete a jaké služby poskytuje?}

29 odpovếdí

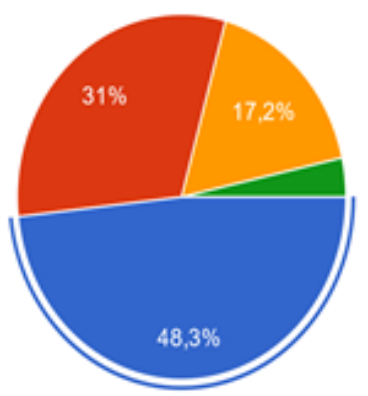

Ano, vim kde je a ønám jeji webove stránky https $: /$ pages .pedf.cuni.cz' poradnal, kde naleznu wsechny informace

- Ano, vim kde je, ale zatim jsem si o poskyłovaných sluz̋ách nic neżiš́foval:

Ano, vim, ze exístuje, ale nevim, kde je, ani jaké sluz̆by poskytuje

- Ne, o Akademické poradně uubec nevím

menost s činnostmi poradny. 
Graf 5. Percepce Akademické poradny.

Jednou z důležitých služeb Akademické poradny je kabinet pomůcek, který nabízí bezplatné zapůjčení elektroniky a dalších kompenzačních pomůcek. Jedna z otázek dotazníku cílila i na tuto službu.

Téměř polovina účastníků šetření vypověděla, že o této možnosti ví, ale nevyužívá ji, 17 \% respondentů pak o této možnosti ví a využíváji. Zajímavá je odpověd' téměř 14 \% účastníků, kteří o této možnosti vědí,

\begin{tabular}{|l|c|c|}
\hline \multicolumn{3}{|c|}{ Tabulka 2. Využivání kabinetu pomücek. } \\
\hline Výpovědi studentü: & $\begin{array}{c}\text { Počet } \\
\text { studentu் }\end{array}$ & $\%$ \\
\hline Ano, o této možnosti vím a využívám ji. & 5 & 17,2 \\
\hline $\begin{array}{l}\text { Ano, o této možnosti vím, ale žádnou takovou pomu̇cku bych } \\
\text { nevyužil/a. }\end{array}$ & 13 & 44,8 \\
\hline $\begin{array}{l}\text { Ano, o této možnosti vím, ale nevím, zda je nabídka určena i } \\
\text { pro mne. }\end{array}$ & 4 & 13,8 \\
\hline
\end{tabular}

ale nejsou si jisti, zda je určena také pro ně.

V další otázce jsme se studentů se SP dotazovali, jakým zpo̊sobem se jim daří překonávat obtíže vyplývající z jejich specifických potřeb. Celkem 16 z nich se daří překonávat obtíže prostřednictvím komunikace s vyučujícími. 14 respondentů se pak snaží obtíže řešit vlastními kompenzačními mechanismy. Dále studenti vypovídají, že své obtíže řeší ve spolupráci s pracovníky Akademické poradny, kontakt-

Tabulka 3. Řešení obtiží vyplývající ze specifických potřeb.

\begin{tabular}{|c|c|}
\hline Výpovědi studentú: & $\begin{array}{c}\text { Počet } \\
\text { studentú }\end{array}$ \\
\hline $\begin{array}{l}\text { Student svou situaci řešil (s vyučujícím/kontaktní osobou } \\
\text { katedry), avšak toto jednání nepřineslo výsledek. }\end{array}$ & 3 \\
\hline 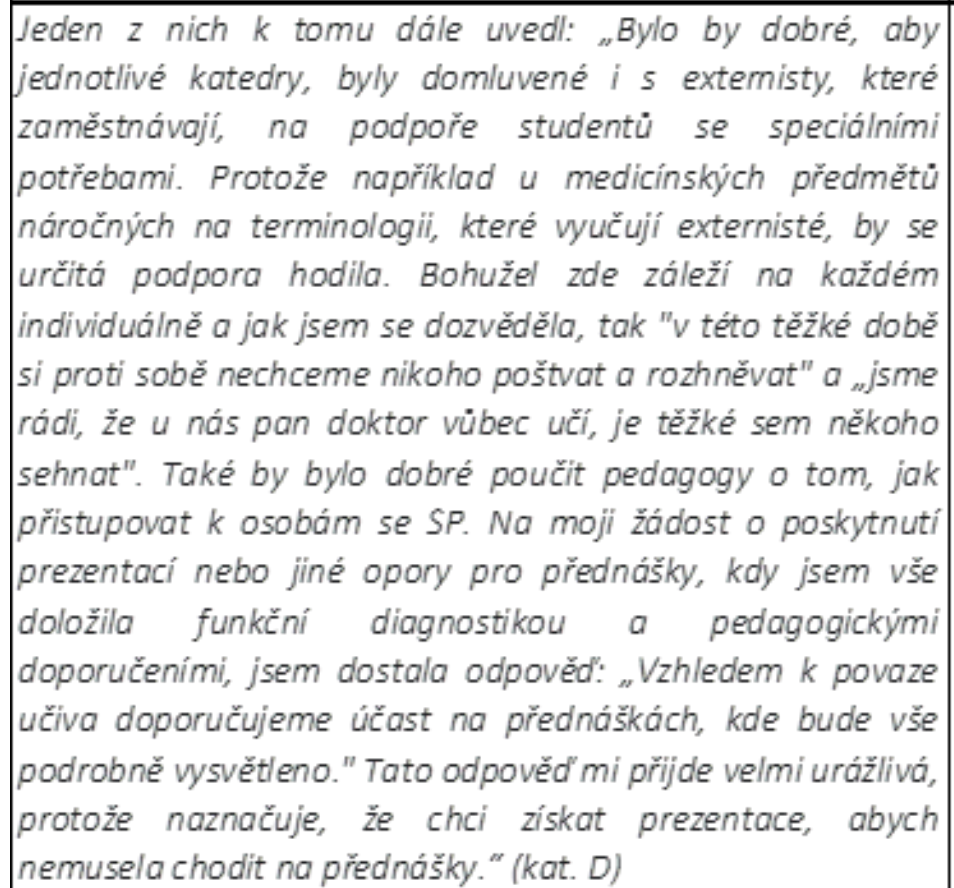 & \\
\hline $\begin{array}{l}\begin{array}{l}\text { Student přiznává, že své obtiže neřešil s dostatečným } \\
\text { předstihem. }\end{array} \\
\text { la }\end{array}$ & 2 \\
\hline $\begin{array}{l}\text { Student žádné obtiže vyplývající z jejich speciálních potřeb } \\
\text { nevnímá. }\end{array}$ & 4 \\
\hline $\begin{array}{l}\text { Student hledal podporu také mimo fakultu - např. v podobě } \\
\text { psychologické podpory (kat. F) či canisterapie (kat. F). }\end{array}$ & 2 \\
\hline
\end{tabular}


ními osobami na katedře/fakultě, což je standardní forma řešení.

\subsection{Hodnocení služeb vyučujícími}

V první otázce jsme se zabývali, zda se studenti se SP na kontaktní osoby kateder obracejí. Kontaktní osoba, i když to není speciální pedagog nebo psycholog, prošla zaškolením v problematice a je připravena řešit problémy studentů se SP ve studiu.

Z výsledků vyplývá, že 62 \% vyučujících různých kateder uvádí v různé míře spolupráci se studenty se SP (odpověd' ano, spíše ano). Jedna pětina vyučujících má zkušenost, že studenti se SP jsou schopni si v rámci statutu studenta se SP vyřešit potřebné sami. K tomu podle nich přispívá celková obeznámenost s problematikou na katedře. Zbývající odpovědi vyučujících (17\%) je možné interpretovat jako zatím nepř́liš funkčně nastavenou spolupráci - tito vyučující o svých studentech se SP zatím neví, protože se na

Obraceji se na Vás studenti Vaši katedry? Jste v těsném kontaktu?

24 odpovēéi
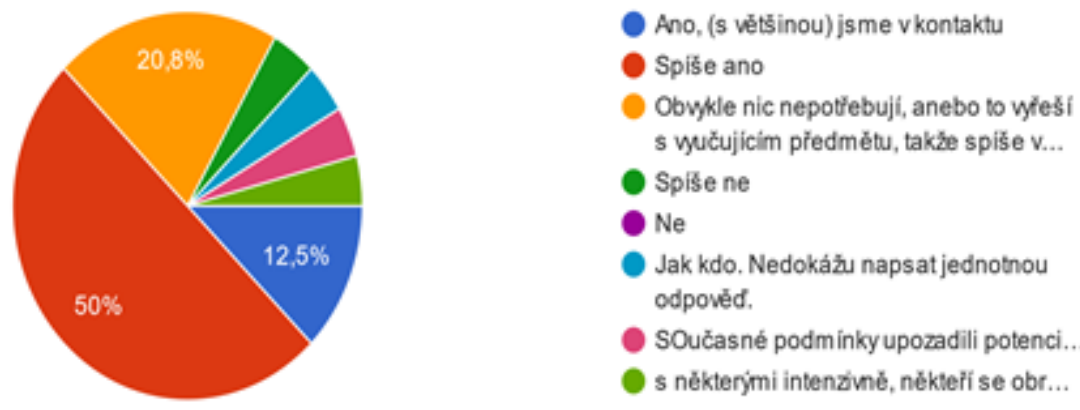

ně studenti se SP neobracejí.

Graf 6. Kontaktování katedrové kontaktní osoby studenty se SP .

Podobně jako u studentů, tak i kontaktních osob z kateder, jsme zjišt'ovali jejich obeznámenost s činností Akademické poradny. Většina z nich je obeznámena, jen malý počet vyučujících zatím neměl s porad-

\footnotetext{
Máte přehled o službách, které poskytuje Akademická poradna pro studenty UK?

24 odpovẽdi
}

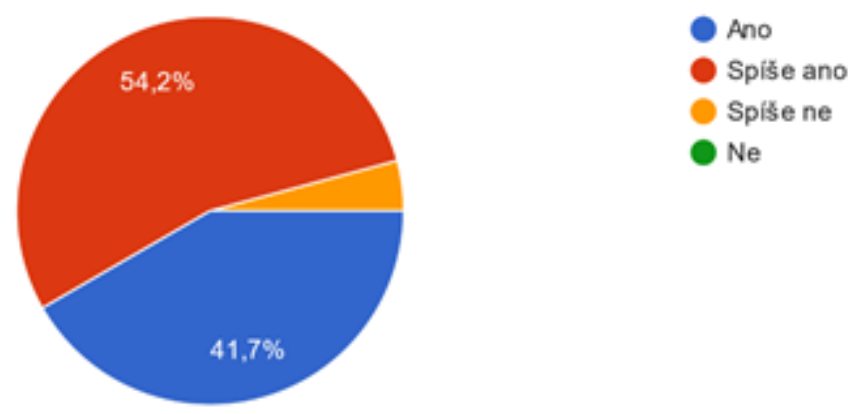

nou žádnou zkušenost a nic o její nabídce neví.

Graf 7. Povědomí vyučujících o Akademické poradně.

\section{Diskuse}

Šetření poukázalo na relativně dobrou informovanost studentů. Studenti vědí, na koho se obracet a s přístupem k informacím nemají problém. Přikládáme to zejména snaze o co nejlepší viditelnost, na které dlouhodobě pracujeme (informační panely na fakultě, webové stránky pro studenty se SP). Překvapivé je, že více než polovina studentů se SP uvádí, že nepotřebuje žádnou podporu při studiu.

Dále se ukázalo, že ne všichni studenti jsou vybaveni dostatečnými a zejména správnými infor- 
macemi. Ačkoli se jednalo o ojedinělé odpovědi, přesto několik studentů ještě do systému podpory na fakultě neproniklo anebo neví, zda jsou všechny služby Akademické poradny určené i jim. Někteří nevěděli, kdo je kontaktní osobou jejich funkční diagnostiky či na koho se v případě potřeby mohou obracet.

Pro větší obeznámenost a spolupráci jsme nově zř́idili on-line konzultace ve stanoveném čase, lze se ale i přizpůsobit studentovu přání. Pravidelně informujeme prostřednictvím e-mailu o službách pro studenty se SP, o novinkách a zajímavých akcích.

Jako možný efektivní nástroj pro zvýšení informovanosti studentů se SP, jak ukázalo naše šetření, může být vytvoření brožury pro studenty se SP (SpecInfo), kde naleznou přehledné informace od procesu tvorby posudku funkční diagnostiky, přes komunikaci s kontaktní osobou katedry až po možné modifikace a zajímavé aktivity pro studenty se SP. Noví studenti se SP od roku 2021/22 nastupují na fakultu s již vytvořenou brožurou SpecInfo.

Z našich poznatků vyplývá, že cílit při propagaci služeb Akademické poradny pouze na studenty se SP není dostatečné. Zaměřujeme se i na nerozpoznané studenty, kteří mezi studenty se SP spadají, avšak z různých důvodů se mezi ně prozatím nezaregistrovali - čili cílit na všechny studenty. Zejména jde o propagaci psychologických služeb, které Akademická poradna zdarma poskytuje, a které jsou důležité z hlediska „covidové“ zkušenosti s dopadem na psychiku studentů.

Z dotazníkového šetření dále vyplynulo, že je vhodné tzv. „sítování“, kdy se okolo studenta, který se nachází v tíživé situaci, vytvoří podpůrná sít. Je tvořena úzkou spoluprací referentky pro studenty se SP, kontaktní osobou katedry a kontaktní osobou funkční diagnostiky. Je-li to možné, je velmi vhodné do procesu zapojit také vyučujícího a odborníka nácviku studijních strategií, pokud jej student využívá.

Za důležité vnímáme budování vlastních kompenzačních mechanismů studentů. Studenty vybavujeme zajímavou nabídkou doprovodných kurzů a aktivit, počínaje akademickým rokem 2020/2021 pro ně pořádáme každý semestr jeden vzdělávací kurz, který je zaměřený na budování studijních strategií. Našimi aktivitami se také snažíme přispět k vyšší duševní odolnosti studentů - v LS jsme pro ně připravili kurz Jógy pro studenty se znevýhodněním.

Posledním zjištěním, na které je potřeba ukázat, je naše dobrá zkušenost s evaluačními dotazníky. Každý rok přinesou nové podněty a jsou prostředkem pro zvyšování kvality podpory studentů se SP i dalších ohrožených skupin studentů ve studiu.

\section{Závěr}

Přestože výsledky ukazují na velmi dobrou součinnost všech podpůrných aparátů (referentky, kontaktních osob katedry/fakulty a pracovníků Akademické poradny) ve prospěch studentů se SP, považujeme za důležité tuto spolupráci nadále upevňovat a koordinovat s cílem co nejefektivnější podpory studentů se SP. Jako možný způsob upevňování této spolupráce může být zasílání informačního newsletteru, o nějž projevili zájem i samotné kontaktní osoby. Jako potřebnou vnímáme také propagaci podpůrných služeb mezi všechny studenty fakulty - tedy i ty bez specifických potřeb, kteří jsou u nás registrováni. Mezi studujícími jsou jistě i studenti se specifickými potřebami, kteří podporu čerpat nechtějí anebo nepotřebují, ovšem také jsou mezi nimi zajisté zastoupeni studenti, kteří by podporu uvítali, ale není v jejich možnostech ji aktivně vyhledat. Takové studenty je třeba vyhledávat a oslovovat co nejadresněji - skrze e-mail, informační panely fakulty, studentské spolky. Za efektivní zpo̊sob zvyšování kvality poskytovaných služeb považujeme také členství UK v meziuniverzitních pracovních skupinách, které vytvářejí prostor pro sdílení příkladů dobré praxe.

Příspěvek byl zpracován v rámci projektu ESF pro VŠ II na UK, Registrační číslo: CZ.02.2.69/0.0/0.0/18_056/0013322.

\section{Literatura}

Kucharská, A., Špačková, K., \& Sotáková, H. (2021). Psychological and Educational Support for University Students with Special Needs. Poster ID 6734. The 32th International Congress of Psychology. Praha: 13. - 20. 7. 2021.

Kucharská, A., \& Janyšková, K. Studenti se specifickými potřebami v době distanční výuky na vysoké škole. Sborník z konference Kvalita života 2021. Univerzita v Prešově, Filozofická fakulta. V recenzním řízení.

MŠMT (2021). Pravidla pro poskytování příspěvku a dotací veřejným vysokým školám MŠMT. Dostupné z https:// www.msmt.cz/vzdelavani/vysoke-skolstvi/pravidla-pro-poskytovani-prispevku-a-dotaci-verejnym-vyso- 
kym-2)

MŠMT. SIMS. Sdružené informace matrik studentů. Dostupné z: https://www.msmt.cz/vzdelavani/vysoke-skolstvi/sims-sdruzene-informace-matrik-studentu-1

MŠMT (1998). Zákon č. 111/1998 Sb., o vysokých školách a o změně a doplnění dalších zákonů (zákon o vysokých školách), ve znění účinném od 1. 4.2021.

Peňáz, P. (2021). Statistiky AP3SP. Google Sheets [online]. Středisko Teiresiás Masarykovy univerzity 17.1.2014, poslední verze 1. 2. 2021 [cit.12. 09. 2021]. Dostupné z https://g0o.gl/tq5MW3.

Univerzita Karlova (2017). Opatření rektora 23/3017. Standardy podpory poskytované studentům a uchazečům o studium se speciálnímipotřebami na Univerzitě Karlově. Dostupné z: https://cuni.cz/UK-8144.html

Univerzita Karlova, Pedagogická fakulta (2021). SpecInfo I. Nástup do studia - praktické informace pro studenty se speciálními potřebami. Dostupné z: https://pages.pedf.cuni.cz/poradna/.

\section{Informace o autorech}

\section{doc. PhDr. PaedDr. Anna Kucharská, Ph.D.}

Telefon: + 420775243893

Email: anna.kucharska@pedf.cuni.cz

URL: https://pedf.cuni.cz/PEDF-1389.html

\section{Mgr. Kristýna Janyšková, Ph.D.}

Telefon: + 420723569587

Email: kristyna.janyskova@pedf.cuni.cz

URL: https://pages.pedf.cuni.cz/poradna/specialne-pedagogicke-poradenstvi/kristyna-janyskova/ 